\title{
DIGITALCOMMONS
}

—@WAYNESTATE-

Wayne State University

$1-1-2012$

\section{Identifying Potential Mediators And Moderators Of The Association Be-tween Child Maltreatment And Bullying Perpetration And Victimization In School}

Jun Sung Hong

Wayne State University, fl4584@wayne.edu

Dorothy L. Espelage

University of Illinois at Urbana-Champaign

Andrew Grogan-Kaylor

University of Michigan

Paula Allen-Meares

University of Illinois at Chicago

\section{Recommended Citation}

Hong, J.S., Espelage, D.L., Grogan-Kaylor, A., \& Allen-Meares, P. (2012). Identifying potential mediators and moderators of the association between child maltreatment and bullying perpetration and victimization in school. Educational Psychology Review, 24(2), 167-186. DOI 10.1007/s10648-011-9185-4

Available at: http://digitalcommons.wayne.edu/soc_work_pubs/33

This Article is brought to you for free and open access by the Social Work at DigitalCommons@WayneState. It has been accepted for inclusion in Social Work Faculty Publications by an authorized administrator of DigitalCommons@WayneState. 
NOTICE IN COMPLIANCE WITH PUBLISHER POLICY: This is the author's final accepted manuscript version, post-peer-review, of an article published online 2011.12.26 in Educational Psychology Review, 24(2), 167-186. The final publication is available via Springer at http://dx.doi.org/10.1007/s10648-011-9185-4 


\title{
Identifying Potential Mediators And Moderators Of The Association Be- tween Child Maltreatment And Bullying Perpetration And Victimization In School
}

\author{
JUN SUNG HONG ${ }^{\mathrm{a}}$, DOROTHY L. ESPELAGE ${ }^{\mathrm{b}}$, ANDREW GROGAN-KAYLOR $^{\mathrm{c}}$, PAULA ALLEN-MEARES $^{\mathrm{d}}$ \\ a School of Social Work, Wayne State University, Detroit, MI 48202 (Corresponding Author, f14584@wayne.edu) \\ ${ }^{\mathrm{b}}$ Department of Educational Psychology, University of Illinois at Urbana-Champaign \\ ${ }^{\mathrm{c}}$ School of Social Work, University of Michigan \\ d University of Illinois at Chicago
}

\begin{abstract}
A growing body of literature is demonstrating associations between childhood maltreatment and bullying involvement at school. In this literature review, five potential mediators (explanatory) and three potential moderators (mitigates or exacerbates) of the association between childhood maltreatment and school bullying are proposed. Mediators include emotional dysregulation, depression, anger, and social skills deficits. Moderators reviewed include quality of parent-child relationships, peer relationships, and teacher relationships. Although there might be insurmountable challenges to addressing child maltreatment in primary or universal school-based prevention programs, it is possible to intervene to improve these potentially mediating and moderating factors.
\end{abstract}

Keywords bullying; child welfare; maltreatment; mediators; moderators; school

\section{INTRODUCTION}

A recent report from the U.S. Department of Health and Human Services (2009) indicates that approximately 3 million cases of child maltreatment are reported annually. According to the Centers for Disease Control and Prevention (CDC), child maltreatment is defined as any acts or series of acts of commission (physical, emotional, and sexual abuse) or omission (neglect) by a parent or a caregiver, which results in harm, potential for harm, or threat of harm to a child (Leeb, Paulozzi, Melanson, Smith, \& Arias, 2008). The Child Abuse Prevention and Treatment Act (CAPTA) also defines child maltreatment as "any recent act or failure to act on the part of a parent or caretaker that results in death, serious physical or emotional harm, sexual abuse, or exploitation or that presents an imminent risk of serious harm" (as cited by Child Welfare Information Gateway, 2007). Since the 1960s, child maltreatment has been a major focus of social research (Tajima, 2004), and during the past 30 years, there has been unprecedented interest in child outcomes associated with experiences in maltreatment (English, 1998). Findings from studies have consistently reported that children and adolescents who are physically, emotionally, and sexually abused are likely to engage in risk-taking (Bornovalova, Gwadz, Kazler, Aklin, \& Lejuez, 2008; Holmes, 2008; Roode, Dickson, Herbison, \& Paul, 2009) and delinquent (Stewart, Livingston, \& Dennison, 2008) behaviors.

Recent events in the United States, such as school shootings and bully-cide (i.e., suicide attributed to bullying victimization) have also generated a major research interest in understanding factors that are associated with children's experiences in bullying perpetration and victimization in school (see Garbarino, 2004). Although a number of definitions of bullying perpetration and victimization exist in research, bullying is commonly identified as verbal, physical, or social forms of aggression, inflicted by an individual or a group of individuals, and directed against a child or adolescent who is not able to defend himself or herself (see Espelage \& Swearer, 2003, for a review). Individuals can be perpetrators, victims, or both. Bullying perpetration and victimization differ from normal peer conflict because the aggression is proactive, intentional, repeated, and involves differential power relationships (Olweus, 1993). Although the exact prevalence of bullying perpetration and victimization in schools is difficult to ascertain due to variations in the measures across studies (Espelage \& Horne, 2008; Espelage \& Swearer, 2003), findings from several studies suggest that bullying is a common occurrence in schools. The National Center for Education Statistics of the U.S. Department of Justice found that in 2007-2008, 25\% of public schools reported that bullying was a daily or weekly occurrence (Robers, Zhang, Truman, \& Snyder, 2010). Studies also consistently report several negative outcomes associated with bullying perpetration and victimization in school, such as depression (Klomek, Marrocco, Kleinman, Schonfeld, \& Gould, 2008; Klomek, Marrocco, Kleinman, Schonfeld, \& Gould, 2007; Sourander et al., 2009), psychopathologic behaviors (Kim, Leventhal, Koh, Hubbard, \& Boyce, 2006), health problems (Rigby, 2003), and suicidal behaviors (Klomek et al., 2009). 
Family is where children first observe and experience interpersonal relationships; it is through the family that children learn what to expect, how to behave, and the necessary interpersonal skills in relationships outside of the home (Stocker \& Youngblade, 1999). Research has documented that maltreatment at home can potentially increase the risk of bullying perpetration and victimization in school (Duncan, 1999; Dussich \& Maekoya, 2007), a relationship which can also be explained by several theories. For instance, attachment theorists argue that abuse during childhood can lead to the development of a negative or insecure attachment with an abusive caregiver (Cicchetti, 1989; Toth, Manly, \& Cicchetti, 1992), which can result in difficulties in establishing positive peer relationships in school. Social learning theorists hypothesize that aggressive behavior is learned and reinforced through child observation of parental modeling of abusive caregivers as well as deviant and antisocial peers (Akers, 1998; Bender, 2010). Finally, life course theorists suggest that bonding to conventional people or institutions that adhere to law-abiding and pro-social behavior would enable children and adolescents to refrain from antisocial behaviors, such as bullying (Bender, 2010; Sampson \& Laub, 1993). Youth who are abused or neglected during childhood may feel disconnected from conventional institutions (e.g., school), and might not develop this critical bond in turn (Bender, 2010). Consequently, these youth may be more likely to engage in aggressive peer interactions.

Despite the significance of research findings and theoretical support, rarely do children who experience violence at home immediately become aggressive individuals (Grogan-Kaylor \& Otis, 2003; Moffitt \& Caspi, 2001; Widom, 1989). Rather violence emerges in some children through complex pathways where a developing child's risk for violence increases with each added exposure to violence or engagement in misconduct as wells as continued exposure to deviant role models (Bender, 2010; Moffitt \& Caspi, 2001). Consistent with Widom's cycle of violence theory, abused and victimized children are at-risk of engaging in violent and delinquent acts (Widom, 1989) yet this propensity is not always realized. Relatedly, children who are victimized at home are also likely to experience developmental, behavioral, interpersonal, and schoolrelated problems, increasing their vulnerability, and placing them at-risk of bullying victimization in school.

The purpose of this article is to enhance our understanding of the relation between maltreatment and bullying perpetration and victimization by examining a number of potential mediating factors that can explain this association, and moderating factors that can either exacerbate or reduce this association. A recent study by Bender (2010), which investigated the linkage between maltreatment and juvenile delinquency, suggested that research studies that focus on identifying mediators and moderators will assist greatly in designing and implementing programs to address the needs of these children and adolescents through child welfare and juvenile justice systems as well as school-based programs.

\section{CURRENT FINDINGS AND RESEARCH GAPS}

Parent-child relationships at home can influence peer relationships outside the home (Bolger \& Patterson, 2001; Knutson, DeGarmo, \& Reid, 2004; Mohr, 2006; Ohene, Ireland, McNeely, \& Borowsky, 2006; Shields \& Cicchetti, 2001). Evidence from research suggests that childhood maltreatment experiences can place adolescents at-risk of bullying victimization and perpetration in school. Findings from several studies also indicate that physical and sexual abuse (Duncan, 1999; Mohr, 2006; Schwartz, Dodge, Pettit, \& Bates, 1997) and parental neglect at home (Bolger \& Patterson, 2001; Bolger, Patterson, \& Kupersmidt, 1998; Chapple, Tyler, \& Bersani, 2005; De Paul \& Arruabarrena, 1995) are significantly associated with greater peer rejection. Chapple et al.'s (2005) longitudinal study found that in a representative community sample, that youth who were emotionally and physically neglected by their parents during childhood were likely to be rejected by their peers in early adolescence and to subsequently develop violent tendencies during late adolescence.

Researchers have also found that abused children are likely to be submissive in an effort to maintain their safety in a violent home situation. These children become easy targets for peer rejection and bullying victimization outside the home (Schwartz, Dodge, \& Coie, 1993) as they are unlikely to retreat or defend themselves when they are victimized by their peers (Shields \& Cicchetti, 2001). An earlier study by Finkelhor and Browne (1985) also proposed that children who are sexually or physically abused can develop a sense of powerlessness and lower selfconfidence, lack of assertiveness, and inability to establish trust with others. Because of this sense of powerlessness, these children may come to expect to be harmed and consequently fail to protect themselves, all of which may lead bullying perpetrators to single them out for targets of bullying victimization.

Studies also report that bullying perpetration is a common outcome of child abuse and neglect (Bolger \& Patterson, 2001; Knutson, DeGarmo, \& Reid, 2004; Knutson \& Schartz, 1997; Ohene et al., 2006). Several researchers have posited that children who are physically, emotionally, or sexually abused, or neglected by their parents or primary caregivers are more likely to experience other forms of victimization outside the family (Cicchetti, Lynch, Shonk, \& Manly, 1992; Shields \& Cicchetti, 2001). Bolger and Patterson's (2001) longitudinal study investigated peer rejection, aggressive behavior, and social withdrawal among a representative community sample of 107 maltreated (physical, emotional, and sexual abuse, and neglect) and an equal number of non-maltreated children. Findings indicate that experiences with abuse were associated with risk of peer rejection repeatedly from childhood to early adolescence, and that abused children were significantly more likely to exhibit aggressive behavior, as reported by peers, teachers, and children themselves. The results held for both boys and girls, from childhood 
through early adolescence, which indicated that negative parent-child interactions can influence children's aggressive behavior while leading to a failure to develop positive interpersonal skills. The researchers hypothesize that parents' failure to use appropriate discipline techniques was a major predictor of children's subsequent aggressive behavior. These researchers have confirmed the existence of maltreatment-bullying association.

Few research studies have focused on the potential mediating and moderating factors between child abuse and neglect and bullying behavior. One possible reason for this gap is that the research literature on bullying and those focusing on child maltreatment have largely developed independent of one another. Also, it is likely to be challenging to assess all forms of child maltreatment within school-based studies given the safeguards around mandated reporting of abuse. On the one hand, child welfare research has identified numerous predictors of maltreatment. On the other hand, a body of school violence research studies has established several risk factors for bullying perpetration and victimization, which is consonant with the broader research literature linking parental behavior with the development of child behavior problems (Gershoff 2002; Gershoff et al., 2010). Bullying behavior encompasses various subcategories (see Hong \& Espelage, forthcoming), such as physical, emotional, mental, and emotional aggression. Despite these subcategories, researchers have commonly identified bullying as a subset of aggressive behavior (Olweus, 1993) directed against a particular individual or a group of individuals. Thus, mediating and moderating factors that are relevant to all forms of maltreatment (i.e., physical, psychological, emotional, and sexual abuse) and bullying perpetration and victimization (i.e., verbal, physical, and social aggression) were considered in this review. We suggest a number of potential mediating and moderating factors that need to be considered in research on child maltreatment and bullying perpetration and victimization, which overlap considerably.

\section{POTENTIAL MEDIATING FACTORS}

A mediator is a variable that intervenes between an independent variable and a dependent variable and that statistically explains some amount of the relationship between the independent variable and the dependent variable. For example, child maltreatment (independent variable) might be associated with depression in children (mediator), which then might in turn be associated with bully perpetration (Baron \& Kenny, 1986). A mediator effect is often tested when there appears to be a significant direct effect between the predictor variable and outcome variable (Baron \& Kenny, 1986; Bennett, 2000); however, when the association between the predictor and outcome variable is more distal (such as childhood abuse with adolescent outcomes), it is also permissible to proceed with the mediator analyses (Shrout \& Bolger, 2002). However, we should also note that even if the relationship tends toward small effect sizes, it is not necessarily weak. In this section, four potential mediating factors explaining maltreatment-bullying perpetration/victimization relationship are examined: 1) emotional dysregulation, 2) depression, 3) anger, and 4) social skills deficit.

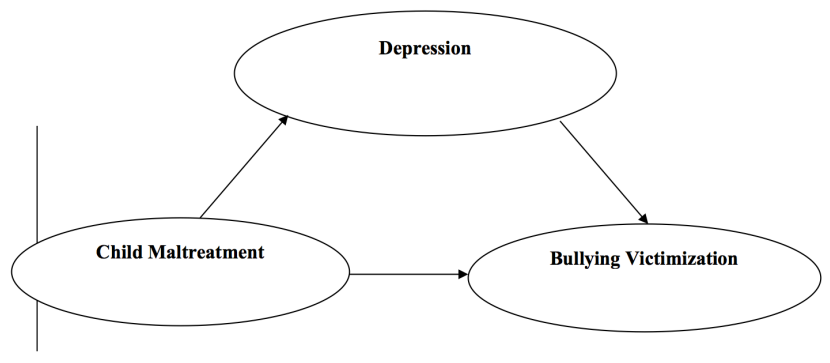

Figure 1. Example of Depression as Mediator of the Association between Child Maltreatment and Bullying Victimization

\section{Emotional Dysregulation}

Emotional dysregulation represents the first mediating factor, which can potentially explicate the relation between child maltreatment and bullying perpetration/victimization. Emotional dysregulation can be defined as the inability of an individual to recognize, understand, and modulate their emotions and to match their emotions to the reality of the situation around them (Gratz \& Roemer, 2004; see also Keenan, 2000). Children who are unable to regulate their emotions may manifest both elevated levels of aggression and antisocial behavior, as well as heightened levels of depression and anxiety, that are not warranted by the particular social situation in which they are involved (Chang, Schwartz, Dodge, \& McBride-Chang, 2003). Children's emotional dysregulation is recognized as a significant outcome of abuse (Gil et al., 2009; Kelly, 1992). As research evidence suggests, physical and emotional abuse and neglect adversely affect children's physical, cognitive, social, and emotional development, which can accumulate over time (English, 1998). Glaser (2000) also argued that physical and emotional abuse and neglect are a potential source of stress, which can increase the likelihood of children's emotional dysregulation. As noted earlier, child maltreatment impedes the ability of a child to develop health models of attachment. A large and growing body of literature has highlighted the importance of the development of healthy attachments in providing a child with the opportunity to develop some level of ability to emotionally regulate (see Cassady \& Shaver, 2008; Mikulincer, Shaver, \& Pereg, 2003; Zimmermann, Maier, Winter, \& Grossmann, 2001), which is associated with quality of peer relationships (Contreras \& Kerns, 2000; Contreras, Kerns, Weimer, Gentzler, \& Tomich, 2000; Kerns, Abraham, Schlegelmilch, \& Morgan, 2007). Consequently when the development of healthy attachment bonds is disrupted, as in the case of situations where parents maltreat their chil- 
dren, the development of ability to emotionally selfregulate is seriously compromised.

Children transfer negative emotional response strategies they have acquired from their parents' punitive and abusive emotions to other contexts (Chang, Schwartz, Dodge, \& Mc-Bride-Chang, 2003). Until recently, there have been relatively few studies on the association between children's emotional dysregulation and bullying perpetration or victimization. A limited number of studies have found that aggressive behavior in school is significantly high for children and adolescents with emotional dysregulation (Chang et al., 2003; Kaukiainen et al., 2002). Chang et al.'s (2003) study reports from a sample of 325 Chinese children and their parents that harsh parenting practices have direct and indirect effect on children's aggressive behavior in school through the mediating process of children's emotional dysregulation. Findings from a limited number of research studies also indicate that children with poorly regulated emotion are at-risk of bullying victimization and peer rejection (Shields, Ryan, \& Cicchetti, 2001). There is a well-established literature linking emotional dysregulation to both increased aggression and antisocial behavior as well as to increased anxiety and depression (Leadbeater, Kuperminc, Hertzog, \& Blatt, 1999; Shields \& Cicchetti, 1998; Marsee \& Frick, 2007). Emotional dysregulation is particularly high among peer victimized children who are also identified as aggressive (Schwartz \& Proctor, 2000; Schwartz, Proctor, \& Chien, 2001; Toblin, Schwartz, Gorman, \& Abou-ezzeddine, 2005), compared to passive victims and bullies. Toblin et al. (2005) examined the social-cognitive and behavioral attributes of 240 children in a Los Angeles elementary school identified as 'aggressive victims' (i.e., peer victimized children who display aggressive behavioral tendencies) in comparison to those identified as bullies, passive victims, and normative comparison group. The researchers found that 'aggressive victims' were characterized by impairment in emotional regulation and difficulties across domains of functioning. Aggressive victims may experience problems with displaying proper emotion, which can hamper their ability to successfully establish peer relationships in school and increase the likelihood of bullying victimization. Consequently, these children might exhibit aggressive behavioral tendencies as a result.

\section{Depression}

Depression is the second potential mediator, which explains the association between maltreatment and bullying perpetration or victimization. Studies have consistently shown that physically, emotionally or sexually abused youth report high levels of internalizing behaviors, such as post-traumatic stress disorder (PTSD) (Grassi-Oliverira \& Stein, 2008; Lev-Wiesel, Daphna-Tekoah, \& Hallak, 2009; Runyon \& Kenny, 2002) and depression (Danielson, de Arellano, Kilpatrick, Saunders, \& Resnick, 2005; Gilbert et al., 2009; Stuewig, 2005; Turner, Finkelhor, \& Ormrod,
2006) during childhood, as well as adolescence and adult years (Hussey, Chang, \& Kotch, 2006; Johnsona et al., 2002; Runyon \& Kenny, 2002; Stuewig \& McCloskey, 2005). Such findings are congruent with the growing cross-cultural research literature linking harsh parenting, and harsh physical discipline to increases in internalizing behavior (Gershoff et al., 2010; Han \& Grogan-Kaylor, in press)

Depression has also been empirically linked to bullying victimization and perpetration by a limited number of researchers. Studies have reported that depression has been found to be a common mental health symptom experienced by victims of bullying (see Espelage \& Swearer, 2003, for a review). Longitudinal studies have found bullying victims (Klomek, Marrocco, Kleinman, Schonfeld, \& Gould, 2008; Sourander et al., 2009) and perpetrators (Klomek, Marrocco, Kleinman, Schonfeld, \& Gould, 2007) are likely to be at-risk for subsequent depression. Researchers also report that depression is a predictor of bullying victimization (Klomek et al., 2007; Espelage, Bosworth, \& Simon, 2001; Fekkes, Pijpers, Fredriks, Vogels, \& VerlooveVanhorick, 2005). A study by Fekkes et al. (2005), which examined the association between health-related symptoms and bullying victimization among 1,118 school-age children in the Netherlands, found that children with depressive symptoms were significantly more likely of being newly victimized by their peers than children who had a history of victimization. The researchers theorized that depressed or anxious behaviors could make the child an easy target for bullying victimization, as they appear to be more vulnerable than children without depression or anxiety. These children are perceived as less likely to stand up for themselves when they are picked on, and the perpetrators may fear less retaliation from them.

\section{Anger}

The third potential mediator, which may explain the relationship of maltreatment to bullying perpetration and victimization, is anger. Studies consistently report that anger is a common adaptive response to physical, emotional, and sexual abuse, and neglect (Bennett, Sullivan, \& Lewis, 2005; Briere \& Elliott, 2003; Harper \& Arias, 2004; Springer, Sheridan, Kuo, \& Carnes, 2007). Victims of abuse struggle with unexplained emotions, such as anger and hostility throughout childhood and then adult years. Springer et al. (2007) explored the impact of physical abuse on mental and physical health of 2,000 men and women, controlling for family background and childhood adversities. Findings from the study indicate that childhood physical abuse by parents was a significant correlate of anger, depression and anxiety.

Anger has also been consistently found to be a significant predictor of bullying and aggression among children and adolescents (Arsenio \& Lemerise, 2001; Bosworth et al., 1999; Camodeca \& Goossens, 2005; Espelage et al., 2001). In particular, anger is a key element of reactive 
aggression (i.e., a defensive response to abuse, which involves both bullies and victims) than proactive aggression (i.e., goal-directed and deliberate action in order to achieve one's goals and involves bullies only; Roland \& Idsoe, 2001). One study (Camodeca \& Goossens, 2005), which examined social information processing and emotion in a bullying situation (both reactive and proactive aggression) of 242 Dutch children, found that both bullies and victims were more likely to exhibit anger and aggressive behavior, compared to children identified as bullies only and those who were not involved in bullying situations. Moreover, anger has also been found to mediate the association between maltreatment at home and peer aggression in school, as indicated in one research finding (Dodge, 1991). Dodge's (1991) study found that children's experience with physical abuse and neglect is a pathway to the development of angry and hyper-vigilant style of interpersonal interactions that could lead to aggressive behaviors toward peers. These findings suggest that anger is a common reaction to abuse in various settings (e.g., home, school). Victimized children may be easily angered and retaliate through bullying and aggression (Arsenio \& Lemerise, 2001).

\section{Social Skills Deficit}

The fourth and final potential mediating factor that could explain the pathway from maltreatment to bullying behavior is that of social skills deficit. Social skills are critical to successful functioning for children and adolescents in school (Schneider, Attilli, Nadel, \& Weissberg, 1989). Healthy and pro-social participation in peer and school settings requires the ability to develop social skills to negotiate situations of potential conflict and disagreement. Most recently, researchers have investigated a wide range of correlates and consequences of poor social skills among children and adolescents (Fox \& Boulton, 2005). Earlier research studies have documented that experiences of physical abuse and neglect can be detrimental to a child's emotional and social skills development (e.g., Browne \& Finkelhor, 1986; Trickett \& Kuczynski, 1986; Zingraff et al., 1993). A more recent study by Ohene, Ireland, McNeely, and Borowsky (2006) also reports that children whose parents employ harsh and abusive disciplinary practices run the risk of developing poor social skills outside the home. Abused and neglected children are more likely to experience difficulty in forming secure attachments with their caregivers than non-abused children. Lack of secure attachments frequently leads to difficulties in establishing positive social relationships outside the family. A study by Elliott, Cunningham, Linder, Colangelo, and Gross (2005), which examined the link between physical abuse and social isolation from the National Youth Survey reported that youth who experienced violence were found to be more socially isolated from their friends and from school than those who had not been physically abused. The researchers note that additional research is needed to identify addition- al mediators of the connection between physical abuse and social isolation. However, the authors theorized that not only is abuse detrimental to secure attachment to others, but lack of attachments to others is related to compromised social skills development and low self-esteem, which in turn are associated with social isolation. Interestingly, one study also reported that parents who physically abuse their children are isolated from their own personal social support networks, which may further influence children's social development because the children are also isolated from role models of adults exhibiting positive social relationships (Howes \& Espinoza, 1985). Although the researchers found that abused children in newly formed peer groups were less socially competent than non-abused children, abused children in well-established peer groups were similar to non-abused children in frequency of social interactions and in their expression of positive emotions. They concluded that abused children might benefit from social skills instruction when interacting within well-established peer groups.

Several researchers consistently report that children with poorly developed social skills and those who are socially withdrawn are more likely to experience negative interpersonal relations outside the home, such as bullying and peer conflicts (Champion, Vernberg, \& Shipman, 2004; Dill, Vernberg, Fonagy, Twemlow, \& Gamm, 2004; Fox \& Boulton, 2005). An earlier study by Elliott (1991) found that bully victims lack social skills, have no sense of humour [humor], have a serious 'demeanor' and are incapable of the relaxed give and take of everyday life" (p. 11), which suggests that social skills training programs for bully victims are indicated (DeRosier, 2004; Fox \& Boulton, 2003). A limited number of studies also report that victims of bullying display non-assertive behavior, making them vulnerable to victimization (Champion et al., 2003; Schwartz, Dodge, \& Cowie, 1993). Champion et al. (2003), for example, found from a sample of 54 early adolescents classified as 'non-bullying victims' that these adolescents have subtle difficulties managing confrontation adaptively in various situations where peer interactions occur. These types of behaviors mark children out as easy targets. Once they are targeted for victimization, these individuals reward the bullying perpetrators through acts of submission (Schwartz et al., 1993).

\section{POTENTIAL MODERATING FACTORS}

A moderator is a categorical variable (e.g., gender, race) or continuous variable (e.g., social support, school belonging) that affects or modifies the strength, and possibly even the direction, of the association between an independent variable and a dependent variable (Baron \& Kenny, 1986). Moderators imply that relations of two variables vary across levels of a third variable - the moderator (Hinshaw, 2007). An examination of moderating factors is important in investigating when or under what conditions the relationship is likely to occur between the independent and 
dependent variables. A number of researchers have commonly identified parent, peer, and school-level risk factors for bullying victimization and perpetration in school (see Hong \& Espelage, forthcoming, for a review). However, little is known empirically as to whether these factors can also potentially inhibit bullying perpetration and victimization.

In this section, three potential moderating factors that could potentially buffer the link between maltreatment and bullying perpetration or victimization are explored: 1) parent-child relationship, 2) peer relationship, and 3) teacher relationship.

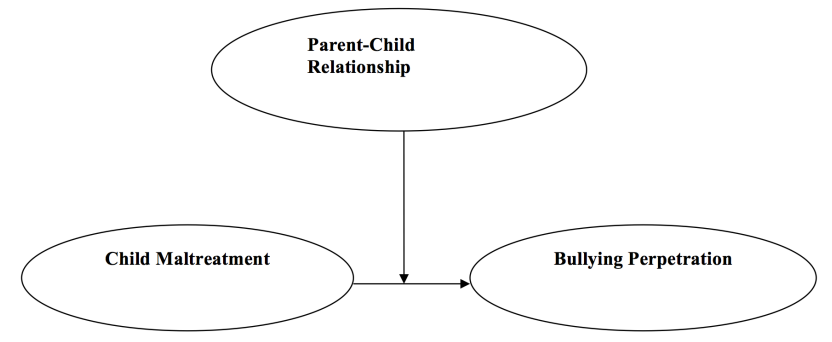

Figure 2. Example of Parent-Child Relationship as a Moderator of the Association between Child Maltreatment and Bullying Perpetration

\section{Parent-Child Relationship}

Empirical evidence from research findings suggest that hostile, conflictive, and distant parent-child relationships are evident in abusive homes and are associated with negative child outcomes, such as bullying perpetration and victimization (Espelage \& Swearer, 2003; Hong \& Espelage, forthcoming). However, despite the presence of maltreatment, a secure relationship and attachment to a nonabusive parent or other caring and supportive adult figure has also been reported as a moderator, which mitigates the negative effects of childhood physical, emotional, and sexual abuse (Aspelmeier, Elliott, \& Smith, 2005; Bacon, 2001; Egeland et al., 1993; Herrenkohl et al., 1994). Aspelmeier et al. (2005) examined the relations between attachment security and psychological functioning of 324 female university students who reported experiencing sexual abuse during childhood. Results from the research indicate that positive relationship and attachment security in parent and peer relationships buffered the negative outcomes of child sexual abuse (e.g., trauma). Other researchers also reported that maltreated children and adolescents who had at least one supportive parent were more likely to develop self-confidence and experience mastery of the environment (Egeland et al., 1993), and remain in school (Herrenkohl et al., 1994). There are parallels in the broader literature on parenting, which provides limited evidence that the presence of a warm and supportive relationship with a parent may to some extent offset the degree to which harsh parenting is associated with the development of problem behaviors. However, it is worth noting that even though a warm and supportive relationship with parents may somewhat moderate other aspects of parenting, an important review of the literature on physical discipline found evidence of many studies that indicated that the relationship between physical punishment and undesirable child outcomes persisted even in the presence of warm and supportive parenting (Gershoff, 2002).

Parent-child relationships shape children and adolescents' interpersonal relationship and socialization skills outside of the family environment. Researchers have consistently found that positive familial relationships and supportive adult figures also reduce youths' propensity to engage in bullying behavior (Baldry \& Farrington, 2005; Espelage, Bosworth, \& Simon, 2000). A study by Baldry and Farrington (2005), which consisted of a sample of 679 male adolescents in an Italian high school, reported that the quality of family relationships could foster or inhibit youths' experiences with bullying and victimization. Results suggested that youth whose parents were characterized as punitive, or with whom youth had a conflictual relationship, were at a heightened risk of bullying and victimization, while those with supportive and authoritative parents were less likely to be involved in bullying and victimization. Findings from Espelage et al.'s (2000) research, which included 558 middle school students in the United States, also indicated that parental physical discipline was positively associated with bullying behavior, while the presence of positive adult role modeling in the home reduced youths' propensity for engaging in bullying at school. Thus, it is imperative that researchers and practitioners further assess the quality of parent-child relationships and parenting practices when examining factors that are associated with bullying and victimization.

\section{Relationship With Peers}

A youth's relationship with peers is the second potentially relevant moderating factor. Negative peer relationships (e.g., deviant peer affiliation) can exacerbate adverse outcomes associated with maltreatment, such as bullying perpetration and victimization. In contrast, positive peer relationships might buffer the effects of maltreatment. Relatively few studies have examined the relations between maltreatment and children's peer association (Fergusson \& Horwood, 1999; Herrenkohl, Huang, Tajima, \& Whitney, 2003; Tyler, Hoyt, Whitbeck, \& Cauce, 2003). Nevertheless, these studies have found that children who are physically, emotionally, or sexually abused at home are more likely to become 'loners' or to establish friendships with deviant and antisocial peer groups (see also Bender, 2010). Likewise, youth who were frequently maltreated are more likely to run away from home where they are susceptible to deviant peer affiliation. This is evident in Tyler et al.'s (2003) study, which investigated the impact of childhood sexual abuse on later sexual victimization among 372 homeless youth in Seattle. The researchers reported that 
sexually abused youth who ran away from home and became homeless then interacted with deviant peers and engaged in risky sexual practices. Moreover, a limited number of studies have also found that maltreated children who are placed in residential care or group home settings through the child welfare system also are likely to be exposed to negative peer influences (Bender, 2010; Dishion, McCord, \& Poulin, 1999; Ryan, Marshall, Herz, \& Hernandez, 2008). In contrast, Lee and Thompson (2009) reported that positive peer influences in a group home setting could potentially buffer the iatrogenic effects of peer group association and relationships by providing structure and expectations for behavior.

Adolescence is a developmental time when friendships and peer affiliations are crucial for healthy identity and social development. Adolescents seek autonomy from their caregivers and turn to their friends and peers for social support (Hong \& Espelage, forthcoming). Findings from a number of researchers (Barboza et al., 2009; Holt \& Espelage, 2007; Mouttapa et al., 2004; Rodkin \& Hodges, 2003; Schmidt \& Bagwell, 2007) suggest that peer association is correlated with involvement in bullying situations. Thus, it is no surprise that negative peer affiliations can be a significant predictor for bullying and aggressive behavior. Longitudinal studies reveal that "deviancy and antisocial training" within adolescent friendships are predictors for subsequent delinquent behavior, substance use, and aggressive behaviors (Dishion, Poulin, \& Burraston, 2002; Poulin, Dishion, \& Burraston, 2001; Weiss et al., 2005). Findings from Dishion, McCord, and Poulin's (1999) two experimentally controlled intervention studies suggest that highrisk adolescents are particularly vulnerable to aggressive peer interactions, compared with low-risk adolescents.

However, positive peer relationships characterized as having high levels of peer acceptance and social support can also be a protective factor against bullying victimization, as evident in research findings. Demaray and Malecki's (2003) research findings indicate that youth with high levels of peer acceptance and peer social support are less likely to be victimized by their peers at school. In addition to peer acceptance and social support, positive friendships can also protect youth from bullying victimization (Bollmer et al., 2005; Hugh-Jones \& Smith, 1999; Schmidt \& Bagwell, 2007). Rigby (2005) found that positive peer relationships and friendships reduced the likelihood of bullying victimization in school among in a sample of 400 elementary and middle school students in Australia.

\section{Relationship With Teachers}

The third potential moderator for the relationship of child maltreatment with bullying perpetration or victimization is children's relationships with teachers at school. A limited number of research findings suggest that physically, emotionally, or sexually abused children face barriers to normal developmental activities, which manifest as poor coping skills in the classroom and school (Miller, 2003). Con- sequently, these children develop negative relationships with their teachers at school (Lynch \& Cicchetti, 1992). On the other hand, some maltreated children with an insecure attachment with their abusive caregiver may turn to teachers as an alternative or secondary attachment figure. Considering that children have frequent contact with their teachers at school, some maltreated children might seek supportive experiences with caring and involved teachers or other non-abusive adult figures (see Lynch \& Cicchetti, 1992).

The quality of teacher-student relationships can also determine whether children are likely to engage in bullying at school. Teacher-student relationships that are characterized as lacking in support and involvement might contribute to bullying in school, as research findings suggest (see Espelage \& Swearer, 2003, for a review). Teachers might foster or prevent bullying incidents, depending on whether they promote positive interactions among students or if they are aware of bullying and conflictual situations with peers among students (Espelage \& Swearer, 2003). Studies have documented that teachers are sometimes not aware of bullying in their classrooms and schools as evidenced by their reporting lower prevalence rates of bullying than teachers (Stockdale, Hangaduambo, Duys, Larson, \& Sarvela, 2002). Considering that teachers are uninvolved or unaware of bullying situations, students are less likely to turn to their teachers when confronted with bullying at school. A study by Rigby and Bagshaw (2003), which asked 7,000 middle school students about their relationships with their teachers and whether their teachers intervened in bullying incidents, found that $40 \%$ responded "not really" or "only sometimes interested" in deterring these behaviors.

\section{DISCUSSION}

Four potentially relevant mediating factors (i.e., emotional dysregulation, depression, anger, and social skills deficits) and three moderating factors (i.e., parent-child relationship, peer relationship, and teacher relationship) were identified in this review. These mediators and moderators need to be further examined empirically, which can enhance our understanding of how physically, emotionally, and sexually abused, and neglected youth are involved in bullying perpetration and victimization at school. The relationship between abuse and neglect and bullying is highly complex, but additional empirical investigations could disentangle the complexity of the pathways linking the two phenomena.

\section{Research Implications}

Despite a dearth of literature available on the connection between child maltreatment and bullying involvement, there appears to be enough support for an association to forge a major research agenda. It is imperative that scholars conducting longitudinal studies on child abuse and neglect assess bullying and victimization experiences, includ- 
ing bullying involvement as a bully, victim, or bully-victim in community, clinical and nationally representative samples. Only with longitudinal data, and appropriately sophisticated statistical analysis, can researchers begin the process of examining the complex relationship between child maltreatment, bullying and victimization, as well as the existence of potential mediators and moderators whose discovery will enrich our scientific understanding of these relationships, and our ability to develop appropriate sophisticated and targeted interventions.

Furthermore, the school-based research community must learn to negotiate with Institutional Review Boards (IRB) in order to appropriately ask about child maltreatment experiences. Indeed, children and adolescents who report current or past maltreatment must be provided with referral information after completing a research protocol and encouraged to seek help from teachers, counselors, or other trusted adults if they are in danger. Most schoolbased bullying researchers have not asked these questions because they have been required by their IRB to report the abuse to school administrators. Researchers must learn to think creatively about how to provide appropriate referrals to services for study participants who indicate that they have been subject to bullying. We will never completely be able to assess the link between maltreatment and bullying involvement in large-scale studies unless we address the human subjects' realities of such research.

That said, future research could also assess constructs related to child maltreatment by studying harsh parenting, sibling aggression or family conflict or hostility. For example, in a sample of American middle-school children, significant differences were found in the prevalence of bullying of and victimization by siblings among bullies, victims, those who were both bullies and victims, and those not involved in bullying (Duncan, 1999). Nearly onethird of students who reported bullying their peers were also bullied by their siblings $(29.03 \%)$. More than half of those who bullied their peers $(56.45 \%)$ reported bullying siblings. Generally, children who witness or experience the perpetration of violence in the home may identify with the perpetrator and may learn that violent and aggressive acts are appropriate behaviors, especially when the behavior goes unpunished (Baldry \& Farrington, 1998; Espelage \& Low, under review). Thus, future research should ask about sibling aggression and witnessing of violence within the home as a proxy of child maltreatment or neglect.

\section{Practice Implications}

Child Welfare Child safety and well-being are paramount to the mission of child welfare. An awareness of the links between child maltreatment in the home and community must incorporate an extended awareness of the school setting as another context in which these relationships may play out. Practitioners must consider the school environment as a place in which victimized children and adolescents are at-risk for re-victimization. Case manage- ment plans must include school-related goals and objectives and community-school collaborations need to be fostered. The differentiation of subpopulations within the category of children who have been maltreated takes on considerable importance in this review of empirical studies and theories. The relationship between child welfare and the fields of counseling and social work practices in the school settings becomes critically important in the design and implementation of preventative and remedial strategies.

We should also note, however, that collaborative efforts between child welfare and school systems have been faced with heavy challenges, considering that few mechanisms exist to support successful collaborations (Altshuler, 2003). Both institutions have different foci and have difficulty working collaboratively with each other, and children who are being served by either system often receive inadequate services from both systems (Altshuler, 1997; Goren, 1996). As suggested by Altshuler (2003), administrators in both child welfare and school settings can help facilitate collaborative efforts through commitment to joint planning and goal setting. Moreover, school social workers, in particular, are in a unique position to bridge a gap between the two systems, as they 'speak the same language' as caseworkers and understand the 'educational language' that permeates school systems (Altshuler, 2003).

School Services Despite the growing evidence that violence in the home is a strong predictor of bullying victimization and perpetration in school (see Espelage \& Low, under review; Swearer et al., 2006), none of the large-scale comprehensive school-based bullying prevention programs or frameworks specifically address exposure to family violence or child maltreatment. However, schoolbased bullying programs can focus on the potential mediating variables of emotional dysregulation, depression, anger, and social skills deficit. One approach that is gaining more attention in bullying prevention is the social emotional learning approach (Frey, Nolen, Van Schoiack Edstrom, \& Hirschstein, 2005). Social-emotional learning as a framework emerged from influences across different movements that focused on resiliency and teaching social and emotional competencies to children and adolescents (Elias et al., 1997). In response, advocates for Social and Emotional Learning (SEL) use social skill instruction to address behavior, discipline, safety, and academics to help youth become self-aware, manage their emotions, build social skills (empathy, perspective-taking, respect for diversity), friendship skill building, and make positive decisions (Zins, Weissberg, Wang, \& Walberg, 2004). A SEL framework includes five interrelated skill areas: self-awareness, social awareness, self-management and organization, responsible problem solving, and relationship management. Recently, a meta-analytic study of more than 213 bullying prevention and intervention programs found that if a school implements a quality SEL curriculum, the school can expect better student behavior and an 11 point increase in standardized test scores (Durlak, Weissberg, Dymnicki, Taylor, 
\& Schellinger, 2011). The gains that schools see in achievement come from a variety of factors - students feel safer and more connected to school and academics, SEL programs build work habits in addition to social skills, and kids and teachers build stronger relationships (Zins et al., 2004).

Indeed, as demonstrated by our review of the potential moderating factors, it is our contention that strong relationships among parents, peers, students, and teachers and staff in classrooms and schools can ameliorate many of the negative outcomes associated with negative home environment. While it is likely that school-based programs will improve the social- emotional skills of individual children and adolescents, some adolescents will need more targeted interventions to fully address their negative home environments.

\section{CONCLUSION}

In summary, to reduce and prevent the occurrence of bullying in our nation's schools, disparate research and theoretical literatures on the various consequences of childhood maltreatment must be thoroughly analyzed and reviewed. In the absence of this effort the development of effective interventions will be at risk. Clearly, the modeling of parental physical, emotional, and sexual abuse, and neglect can have differential outcomes depending on the child's developmental stage, cognition and social skills, and other positive adult role models in their life space. Researchers have consistently found that negative outcomes associated with childhood physical, emotional, and sexual abuse and neglect are likely to occur in multiple contexts, such as family, school, and neighborhood (e.g., Thornberry, Ireland, \& Smith, 2001). Moreover, the effects of child maltreatment are likely to occur in later years. A number of studies have suggested that maltreated children are more likely to experience other forms of violence in later years, such as dating violence during adolescence (Cyr, McDuff, \& Wright, 2006; Wolfe, Scott, Wekerle, \& Pittman, 2001; Wolfe et al., 2004) and domestic violence during adult years (Bevan \& Higgins, 2002; Ehrensaft et al., 2003; Ileana, 2004). Identifying the potential factors that link past experiences of maltreatment to subsequent bullying is the first step, which will illuminate effective strategies for breaking the cycle of violence. This article serves as a blueprint for researchers and practitioners in the fields of school psychology, educational psychology, counseling, and social work in understanding the pathways from maltreatment to bullying perpetration and victimization in school that explain or inhibit this association, which has major implications for research and practice.

\section{REFERENCES}

1. Akers, R. (1998). Social learning and social structure: A general theory of crime and deviance. Boston: Northeastern University Press.
2. Altshuler, S. J. (1997). A reveille for school social workers: Children in foster care need our help! [Trends \& Issues]. Social Work in Education, 19, 121-127.

3. Altshuler, S. J. (2003). From barriers to successful collaboration: Public schools and child welfare working together. Social Work, 48 , 52-63.

4. Arsenio, W. F., \& Lemerise, E. A. (2001). Varieties of childhood bullying: Values, emotion processes, and social competences. Social Development, 10, 59-73.

5. Aspelmeier, J. E., Elliott, A. N., \& Smith, C. H. (2007). Childhood sexual abuse, attachment, and trauma symptoms in college females: The moderating role of attachment. Child Abuse \& Neglect, 31, 549566.

6. Bacon, H. (2001). Attachment, trauma and child sexual abuse: An exploration. In S. Richardson \& H. Bacon (Eds.), Creative responses to child sexual abuse: Challenges and dilemmas (pp. 44-59). London: Jessica Kingsley Publishers.

7. Baldry, A. C., \& Farrington, D. P. (1998). Parenting influences on bullying and victimization. Criminal and Legal Psychology, 3, 237254.

8. Baldry, A. C., \& Farrington, D. P. (2005). Protective factors as moderators of risk factors in adolescence bullying. Social Psychology of Education, 8, 263-284.

9. Barboza, G. E., Schiamberg, L. B., Oehmke, J., Korzeniewski, S. J., Post, L. A., \& Heraux, C. G. (2009). Individual characteristics and the multiple contexts of adolescent bullying: An ecological perspective. Journal of Youth and Adolescence, 38, 101-121.

10. Baron, R. M., \& Kenny, D. A. (1986). The moderator-mediator variable distinction in social psychological research: Conceptual, strategic, and statistical considerations. Journal of Personality and Social Psychology, 51, 1173-1182.

11. Bender, K. (2010). Why do some maltreated youth become juvenile offenders? A call for further investigation and adaptation of youth services. Children and Youth Services Review, 32, 466-473.

12. Bennett, D. S., Sullivan, M. W., \& Lewis, M. (2005). Young children's adjustment as a function of maltreatment, shame, and anger. Child Maltreatment, 10, 311-323.

13. Bennett, J. A. (2000). Mediator and moderator variables in nursing research: Conceptual and statistical differences. Research in Nursing \& Health, 23, 415-420.

14. Bevan, E., \& Higgins, D. J. (2002). Is domestic violence learned? The contribution of five forms of child maltreatment to men's violence and adjustment. Journal of Family Violence, 17, 223-245.

15. Bollmer, J. M., Milich, R., Harris, M. J., \& Maras, M. A. (2005). A friend in need: The role of friendship quality as a protective factor in peer victimization and bullying. Journal of Interpersonal Violence, 20,701-712.

16. Bolger, K. E., \& Patterson, C. J. (2001). Developmental pathways from child maltreatment to peer rejection. Child Development, 72 , 549-568.

17. Bolger, K. E., Patterson, C. J., \& Kupersmidt, J. B. (1998). Peer relationships and self-esteem among children who have been maltreated. Child Development, 69, 1171-1197.

18. Bornovalova, M. A., Gwadz, M. A., Kahler, C., Aklin, W. M., \& Lejuez, C. W. (2008). Sensation seeking and risk-taking propensity as mediators in the relationship between childhood abuse and HIVrelated risk behavior. Child Abuse \& Neglect, 32, 99-109.

19. Bosworth, K., Espelage, D. L., \& Simon, T. (1999). Factors associated with bullying behavior in middle school students. Journal of Early Adolescence, 19, 341-362.

20. Briere, J., \& Elliott, D. M. (2003). Prevalence and psychological sequelae of self-reported childhood physical and sexual abuse in a general population sample of men and women. Child Abuse \& Neglect, 27, 1205-1222.

21. Browne, A., \& Finkelhor, D. (1986). Impact of child sexual abuse: A review of research. Psychological Bulletin, 99, 66-77.

22. Camodeca, M., \& Goossens, F. A. (2005). Aggression, social cognitions, anger and sadness in bullies and victims. Journal of Child Psychology and Psychiatry, 46, 186-197.

23. Cassady, J., \& Shaver, P. R. (Eds.) (2008). Handbook of attachment: Theory, research, and clinical applications ( $2^{\text {nd }}$ ed.), (pp. 348-365). New York: Guilford Press. 
24. Champion, K., Vernberg, E., \& Shipman, K. (2003). Nonbullying victims of bullies: Aggression, social skills, and friendship characteristics. Journal of Applied Developmental Psychology, 24, 535551 .

25. Chang, L., Schwartz, D., Dodge, K. A., \& McBride-Chang, C. (2003). Harsh parenting in relation to child emotion regulation and aggression. Journal of Family Psychology, 17, 598-606.

26. Child Welfare Information Gateway (2007). Definitions in federal law. Retrieved July 14, 2011, from http://www.childwelfare.gov/can/defining/federal.cfm

27. Cicchetti, D. (1989). How research on child maltreatment has informed the study of child development: Perspectives from developmental psychopathology. In D. Cicchetti \& V. Carlson (Eds.), Child maltreatment: Theory and research on the causes and consequences of child abuse and neglect (pp. 377-431). New York: Cambridge University Press.

28. Cicchetti, D., Lynch, M. L., Shonk, S., \& Manly, J. T. (1992). An organizational perspective on peer relations in maltreated children. In R. D. Parke, \& G. W. Ladd (Eds.), Family-peer relationships: Modes of linkage (pp. 345-383). Hillsdale, NJ: Lawrence Erlbaum Associates, Inc.

29. Contreras, J. M., \& Kerns, K. A. (2000). Emotional regulation processes: Explaining links between parent-child attachment and peer relationships. In K. A. Kerns, J. M., Contreras, \& A. M. NealBarnett (Eds.), Family and peers: Linking two social worlds (pp. 137-168). Westport, CN: Praefer.

30. Contreras, J. M., Kerns, K. A., Weimer, B. L., Gentzler, A. L., \& Tomich, P. L. (2000). Emotion regulation as a mediator of associations between mother-child attachment and peer relationships in middle childhood. Journal of Family Psychology, 14, 111-124.

31. Cyr, M., McDuff, P., \& Wright, J. (2006). Prevalence and predictors of dating violence among adolescent female victims of child sexual abuse. Journal of Interpersonal Violence, 21, 1000-1017.

32. Danielson, C. K., de Arellano, M. A., Kilpatrick, D. G., Saunders, B E., \& Resnick, H. S. (2005). Child maltreatment in depressed adolescents: Differences in symptomatology based on history of abuse. Child Maltreatment, 10, 37-48.

33. Demaray, M. K., \& Malecki, C. K. (2003). Perceptions of the frequency and importance of social support by students classified as victims, bullies and bully/victims in an urban middle school. School Psychology Review, 32, 471-489.

34. DeRosier, M. E. (2004). Building relationships and combating bullying: Effectiveness of a school-based social skills group intervention. Journal of Clinical Child \& Adolescent Psychology, 33, 196-201.

35. Dill, E. J., Vernberg, E. M., Fonagy, P., Twemlow, S. W., \& Gamm, B. K. (2004). Negative affect in victimized children: The roles of social withdrawal, peer rejection, and attitudes toward bullying. Journal of Abnormal Child Psychology, 32, 159-173.

36. Dishion, T., McCord, J., \& Poulin, F. (1999). When intervention harm: Peer groups and problem behavior. American Psychologist, $54,755-764$

37. Dishion, T. J., Poulin, F., \& Burraston, B. (2002). Peer group dynamics associated with iatrogenic effect in group interventions with high-risk young adolescents. New Directions for Child and Adolescent Development, 91, 79-92.

38. Dodge, K. A. (1991). The structure and function of reactive and proactive aggression. In D. Pepler \& K. Rubin (Eds.), The development and treatment of childhood aggression (pp. 201-218). Hillsdale, NJ: Erlbaum.

39. Duncan, R. D. (1999). Maltreatment by parents and peers: The relationship between child abuse, bully victimization, and psychological distress. Child Maltreatment, 4, 45-55.

40. Durlak, J. A., Weissberg, R. P., \& Dymnicki, A. B., Taylor, R. D., \& Schellinger, K. B. (2011). The mpact of enhancing students' social and emotional learning: A meta-analysis of school-based universal interventions. Child Development, 82, 405-432.

41. Dussich, J. P. J., \& Maekoya, C. (2007). Physical child harm and bullying-related behaviors: A comparative study in Japan, South Africa, and the United States. International Journal of Offender Therapy and Comparative Criminology, 51, 495-509.
42. Egeland, B., Carlson, E., \& Sroufe, L. A. (1993). Resilience and process. Development and Psychopathology, 5, 517-528.

43. Ehrensaft, M. K., Cohen, P., Brown, J., Smailes, E., Chen, H., \& Johnson, J. G. (2003). Intergenerational transmission of partner violence: A 20-year prospective study. Journal of Consulting and Clinical Psychology, 71, 741-753.

44. Elias, M. J., Zins, J. E., Weissberg, K. S., Greenberg, M. T., Haynes, . M., Kessler, R., et al. (1997). Promoting social and emotional learning: Guidelines for educators. Alexandria, VA: Association for Supervision and Curriculum Development.

45. Elliott, G. C., Cunningham, S. M., Linder, M., Colangelo, M., \& Gross, M. (2005). Child physical abuse and self-perceived social isolation among adolescents. Journal of Interpersonal Violence, 20, 1663-1684

46. Elliott, M. (Ed., 1991). Bullying: A practical guide to coping for schools. Exeter, UK: Longman.

47. English, D. J. (1998). The extent and consequences of child maltreatment. The Future of Children, 8, 39-53.

48. Espelage, D. L., Bosworth, K., \& Simon, T. R. (2000). Examining the social context of bullying behaviors in early adolescence. Journal of Counseling and Development, 78, 326-333.

49. Espelage, D. L., Bosworth, K., \& Simon, T. R. (2001). Short-term stability and prospective correlates of bullying in middle-school students: An examination of potential demographic, psychosocial, and environmental influences. Violence and Victims, 16, 411-426.

50. Espelage, D., \& Horne, A. (2008). School violence and bullying prevention: From research based explanations to empirically based solutions. In S. Brown \& R. Lent (Eds.), Handbook of counseling psychology $\left(4^{\text {th }}\right.$ ed., pp. 588-606). Hoboken, NJ: John Wiley and Sons.

51. Espelage, D. L., \& Low, S. (under review). Relations between peer victimization subtype, family violence, and psychological outcomes during early adolescence. Manuscript under review.

52. Espelage, D. L., \& Swearer, S. M. (2003). Research on school bullying and victimization: What have we learned and where do we go from here? School Psychology Review, 32, 365-383.

53. Fekkes, M., Pijpers, F. I. M., Fredriks, A. M., Vogels, T., \& Verloove-Vanhorick, S. P. (2006). Do bullied children get ill, or do ill children get bullied? A prospective cohort study on the relationship between bullying and health-related symptoms. Pediatrics, 117, 1568-1574.

54. Fergusson, D. M., \& Horwood, L. J. (1999). Prospective childhood predictors of deviant peer affiliation in adolescence. Journal of Child Psychology and Psychiatry, 40, 581-592.

55. Frey, K. S., Nolen, S. B., Van Schoiack Edstrom, L., \& Hirschstein, M. K. (2005). Effects of a school-based social-emotional competence program: Linking children's goals, attributions and behavior. Journal of Applied Developmental Psychology, 26, 171-200.

56. Fox, C., \& Boulton, M. (2003). Evaluating the effectiveness of a social skills training (SST) programme for victims of bullying. Educational Research, 45, 231-247.

57. Fox, C. L., \& Boulton, M. J. (2005). The social skills problems of victims of bullying: Self, peer and teacher perceptions. British Journal of Educational Psychology, 75, 313-328.

58. Garbarino, J. G. (2004). Foreword. In D. L. Espelage \& S. M. Swearer (Eds.), Bullying in American schools: A social-ecological perspective on prevention and intervention ( $\mathrm{pp}$. xi-xiii). Mahwah, NJ: Lawrence Erlbaum Associates, Inc.

59. Gershoff, E. T. (2002). Corporal punishment by parents and associated child behaviors and experiences: A meta-analytic and theoretical review. Psychological Bulletin, 128, 539-579.

60. Gershoff, E. T., Grogan-Kaylor, A., Lansford, J. E., Chang, L., Zelli, A., Deater-Deckard, K., \& Dodge, K. A. (2010). Parent discipline practices in an international sample: Associations with child behaviors and moderation by perceived normativeness. Child Development, 81, 487-502.

61. Gil, A., Gama, C. S., de Jesus, D. R., Lobato, M. I., Zimmer, M., \& Belmonte-de-Abreu, P. (2009). The association of child abuse and neglect with adult disability in schizophrenia and the prominent role of physical neglect. Child Abuse \& Neglect, 33, 618-624.

62. Gilbert, R., Widom, C. S., Browne, K., Fergusson, D., Webb, E., \& Janson, S. (2009). Child maltreatment 1: Burden and consequences 
of child maltreatment in high-income countries. The Lancet, 373, 68-81.

63. Glaser, D. (2000). Child abuse and neglect and the brain: A review. Journal of Child Psychology and Psychiatry, 41, 97-116.

64. Goren, S. G. (1996). Child protection and the school social worker. In R. Constable, S. McDonald, \& J. P. Flynn (Eds.), School social work : Practice, policy \& research perspectives (pp. 355-366). Chicago : Lyceum Books.

65. Grassi-Oliveira, R., \& Stein, L. M. (2008). Childhood maltreatment associated with PTSD and emotional distress in low-income adults: The burden of neglect. Child Abuse \& Neglect, 32, 1089-1094.

66. Gratz, K. L., \& Roemer, L. (2004). Multidimensional assessment of emotion regulation and dysregulation: Development, factor structure and initial validation of the difficulties in emotion regulation scale. Journal of Psychopathology and Behavioral Assessment, 26, 41-54.

67. Grogan-Kaylor, A., \& Otis, M. (2007). The predictors of parental use of corporal punishment. Family Relations, 56, 80-91.

68. Han, Y., \& Grogan-Kaylor, A. (in press). Parenting and youth mental health in South Korea using fixed effects model. Journal of Family Issues.

69. Harper, F. W. K., \& Arias, I. (2004). The role of shame in predicting adult anger and depressive symptoms among victims of child psychological maltreatment. Journal of Family Violence, 19, 359-367.

70. Herrenkohl, E. C., Herrenkohl, R. R., \& Egolf, B. (1994). Resilient early school-age children from maltreating homes: Outcomes in late adolescence. American Journal of Orthopsychiatry, 64, 301-309.

71. Herrenkohl, T. I., Huang, B., Tajima, E. A., \& Whitney, S. D. (2003). Examining the link between child abuse and youth violence: An analysis of mediating mechanisms. Journal of Interpersonal Violence, 18, 1189-1208.

72. Hinshaw, S. P. (2007). Moderators and mediators of treatment outcome for youth with ADHD: Understanding for whom and how interventions work. Journal of Pediatric Psychology, 32, 664-675.

73. Holmes, W. C. (2008). Men's self-definition of abusive childhood sexual experiences, and potentially related risky behavioral and psychiatric outcomes. Child Abuse \& Neglect, 32, 83-97.

74. Holt, M. K., \& Espelage, D. L. (2007). Perceived social support among bullies, victims, and bully-victims. Journal of Youth and Adolescence, 36, 984-994.

75. Hong, J. S., \& Espelage, D. L. (forthcoming). A review of research on bullying and peer victimization in school: An ecological systems analysis.

76. Howe, C., \& Espinosa, M. P. (1985). The consequences of child abuse for the formation of relationships with peers. Child Abuse \& Neglect, 9, 397-404.

77. Hugh-Jones, S., \& Smith, P. K. (1999). Self-reports of short- and long-term effects of bullying on children who stammer. British Journal of Educational Psychology, 69, 141-158.

78. Hussey, J. M., Chang, J. J., \& Kotch, J. B. (2006). Child maltreatment in the United States : Prevalence, risk factors, and adolescent health consequences. Pediatrics, 118, 933-942.

79. Ileana, A., (2004). The legacy of child maltreatment : Long-term health consequences for women. Journal of Women's Health, 13, 468-473.

80. Johnsona, R. M., Kotch, J. B., Catellier, D. J., Winsor, J. R., Duroft, V., Hunter, W., \& Amaya-Jackson, L. (2002). Adverse behavioral and emotional outcomes from child abuse and witnessed violence. Child Maltreatment, 7, 179-186.

81. Kim, Y. S., Leventhal, B. L., Koh, Y. J., Hubbard, A., \& Boyce, W T. (2006). School bullying and youth violence: Causes or consequences of psychopathologic behavior? Archives of General Psychiatry, 63, 1035-1041.

82. Kaukiainen, A., Salmivalli, C., Lagerspetz, K., Tamminen, M., Vauras, M., Maki, H., et al. (2002). Learning difficulties, social intelligence, and self-concept: Connections to bully-victim problems. Scandinavian Journal of Psychology, 43, 269-278.

83. Keenan, K. (2000). Emotion dysregulation as a risk factor for child psychopathology. Clinical Psychology: Science and Practice, 7, 418-434.

84. Kelly, L. (1992). The connections between disability and child abuse: A review of the research evidence. Child Abuse Review, 1, 157-167.
85. Kerns, K. A., Abraham, M. M., Schlegelmilch, A., \& Morgan, T. A. (2007). Mother-child attachment in later middle childhood: Assessment approaches and associations with mood and emotion regulation. Attachment \& Human Development, 9, 33-53.

86. Klomek, A. B., Marrocco, F., Kleinman, M., Schonfeld, I. S., \& Gould, M. S. (2007). Bullying, depression, and suicidality in adolescents. Journal of the American Academy of Child and Adolescent Psychiatry, 46, 40-49.

87. Klomek, A. B., Marrocco, F., Kleinman, M., Schonfeld, I. S., \& Gould, M. S. (2008). Peer victimization, depression, and suicidality in adolescents. Suicide and Life-Threatening Behavior, 38, 166-180.

88. Klomek, A. B., Sourander, A., Niemela, S., Kumpulainen, K., Piha, J., Tamminen, T., et al. (2009). Childhood bullying behaviors as a risk for suicide attempts and completed suicides: A populationbased birth cohort study. Journal of the American Academy of Child \& Adolescent Psychiatry, 48, 254-261.

89. Knutson, J. F., DeGarmo, D. S., \& Reid, J. B. (2004). Social Disadvantage and neglectful parenting as precursors to the development of antisocial and aggressive child behavior: Testing a theoretical model. Aggressive Behavior, 30, 187-205.

90. Knutson, J. F., \& Schartz, H. A. (1997). Physical abuse and neglect of children. In T.A. Widiger, A. J. Frances, H. A. Pincus, R. Ross, M. B. First, \& W. Davis (Eds.), DSM-IV Sources, Vol. 3 (pp. 713 804). Washington, DC: American Psychiatric Association Press.

91. Leadbeater, B. J., Kupermine, G P., Hertzog, C., \& Blatt, S. J. (1999). A multivariate model of gender differences in adolescents' internalizing and externalizing problems. Developmental Psychology, 35, 1268-1282.

92. Lee, B. R., \& Thompson, R. (2009). Examining externalizing behavior trajectories of youth in group homes: Is there evidence for peer contagion? Journal of Abnormal Child Psychology, 37, 31-44.

93. Lee, V., \& Hoaken, P. N. S. (2007). Cognition, emotion, and neurobiological development: Mediating the relation between maltreatment and aggression. Child Maltreatment, 12, 281-298.

94. Leeb, R. T., Paulozzi, L., Melanson, C., Smith, T., \& Arias, I. (2008). Child maltreatment surveillance: Uniform definition for public health and recommended data elements, Version 1.0. Centers for Disease Control and Prevention, National Center for Injury Prevention and Control.

95. Atlanta, G.A., Lev-Wiesel, R., Daphna-Tekoah, S., \& Hallak, M. (2009). Childhood sexual abuse as a predictor of birth-related posttraumatic stress and postpartum posttraumatic stress. Child Abuse \& Neglect, 33, 877-887.

96. Little, L. (2002). Middle-class mothers' perceptions of peer and sibling victimization among children with Asperger's syndrome and nonverbal learning disorders. Issues in Comprehensive Pediatric Nursing, 25, 43-57.

97. Lynch, M., \& Cicchetti, D. (1992). Maltreated children's reports of relatedness to their teachers. New Directions for Child and Adolescent Development, 57, 81-107.

98. Manly, J. T., Kim, J. E., Rogosch, F. A., \& Ciccheti, D. (2001). Dimensions of child maltreatment and children's adjustment: Contributions of developmental timing and subtype. Development \& Psychopathology, 13, 759-782.

99. Marsee, M. A., \& Frick, P. J. (2007). Exploring the cognitive and emotional correlates to proactive and reactive aggression in a sample of detained girls. Journal of Abnormal Child Psychology, 35, 969-981.

100. Mikulincer, M., Shaver, P. R., \& Pereg, D. (2003). Attachment theory and affect regulation: The dynamics, development, and cognitive consequences of attachment-related strategies. Motivation and Emotion, 27, 77-102.

101. Miller, K. (2003, February). Understanding and treating reactive attachment disorder. A workshop presented by Medial Educational Services, Eau Claire, Wisconsin . Arlington, TX.

102. Moffitt, T. E., \& Caspi, A. (2001). Childhood predictors differentiate life-course persistent and adolescence-limited antisocial pathways among males and females. Development and Psychopathology, $13,355-375$.

103. Mohr, A. (2006). Family variables associated with peer victimization: Does family violence enhance the probability of being victimized by peers? Swiss Journal of Psychology, 65, 107-116. 
104. Mouttapa, M., Valente, T., Gallaher, P., Rohrbach, L. A., \& Unger, J. B. (2004). Social network predictors of bullying and victimization. Adolescence, 39, 315-335.

105. Ohene, S. -A., Ireland, M., McNeely, C., \& Borowsky, I. W. (2006). Parental expectations, physical punishment, and violence among adolescents who score positive on a psychosocial screening test in primary care. Pediatrics, 117, 441-447.

106. Olweus, D. (1993). Bully/victim problems among school-children: Long-term consequences and an effective intervention program. In S. Hodgins (Ed.), Mental disorder and crime (pp. 317-349). Thousand Oaks, CA: Sage Publications.

107. Poulin, F., Dishion, T. J., \& Burraston, B. (2001). 3-year iatrogenic effects associated with aggregating high-risk adolescents in cognitive-behavioral preventive interventions. Applied Developmental Science, 5, 214-224.

108. Rigby, K. (2003). Consequences of bullying in schools. The Canadian Journal of Psychiatry, 48, 583-590.

109. Rigby, K. (2005). Why do some children bully at school? School Psychology International, 26, 147-161.

110. Rigby, R., \& Bagshaw, D. (2003). Prospects of adolescent students collaborating with teachers in addressing issues of bullying and conflict in schools. Educational Psychologist, 23, 535- 546.

111. Robers, S., Zhang, J., Truman, J., \& Snyder, T. D. (2010). Indicators of School Crime and Safety: 2010 (NCES 2011-002/NCJ 230812). National Center for Education Statistics, U.S. Department of Education, and Bureau of Justice Statistics, Office of Justice Programs, U.S. Department of Justice. Washington, DC.

112. Rodkin, P. C., \& Hodges, E. V. E. (2003). Bullies and victims in the peer ecology: Four questions for psychologists and school professionals. School Psychology Review, 32, 384-400.

113. Roland, E., \& Idsoe, T. (2001). Aggression and bullying. Aggressive Behavior, 27, 446-462.

114. Roode, T. v., Dickson, N., Herbison, P., \& Paul, C. (2009). Child sexual abuse and persistence of risky sexual behaviors and negative sexual outcomes over adulthood: Findings from a birth cohort. Child Abuse \& Neglect, 33, 161-172.

115. Runyon, M. K., \& Kenny, M. C. (2002). Relationship of attributional style, depression, and posttrauma distress among children who suffered physical or sexual abuse. Child Maltreatment, 7, 254-264.

116. Ryan, J. P., Marshall, J. M., Herz, D., \& Hernandez, P. M. (2008). Juvenile delinquency in child welfare: Investigating group home effects. Children and Youth Services Review, 30, 1088-1099.

117. Sampson, R. J., \& Laub, J. H. (1993). Crime in the making. Cambridge, MA: Harvard University Press.

118. Schmidt, M. E., \& Bagwell, C. L. (2007). The protective role of friendships in overtly and relationally victimized boys and girls. Merrill-Palmer Quarterly, 53, 439-460.

119. Schwartz, D., Dodge, K. A., \& Cowie, J. D. (1993). The emergence of chronic peer victimization in boy's play groups. Child Development, 64, 1755-1772.

120. Schwartz, D., Dodge, K. A., Pettit, G. S., \& Bates, J. E. (1997). The early socialization of aggressive victims of bullying. Child Development, 68, 665-675.

121. Schwartz, D., McFadyen-Ketchum, S., Dodge, K. A., Pettit, G. S., \& Bates, J. E. (1999). Early behavior problems as a predictor of later peer group victimization: Moderators and mediators in the pathways of social risk. Journal of Abnormal Child Psychology, 27, 191-201.

122. Schwartz, D., \& Proctor, L. (2000). Community violence exposure and children's social adjustment in the school peer group: The mediating roles of emotion regulation and social cognition. Journal of Consulting and Clinical Psychology, 68, 670-683.

123. Schwartz, D., Proctor, L. J., \& Chien, D. H. (2001). The aggressive victim of bullying: Emotional and behavioral dysregulation as a pathway to victimization by peers. In J. Juvonen \& S. Graham (Eds.), Peer harassment in school: The plight of the vulnerable and victimized (pp. 147-174). New York: Guilford Press.

124. Schneider, B. H., Attilli, G., Nadel, J., \& Weissberg, R. P. (1989). Social competence in developmental perspective. Dordrecht: Kluwer.

125. Shields, A., \& Cicchetti, D. (1998). Reactive aggression among maltreated children: The contributions of attention and emotion dysregulation. Journal of Clinical Child Psychology, 27, 381-395.
126. Shields, A., \& Cicchetti, D. (2001). Parental maltreatment and emotion dysregulation as risk factors for bullying and victimization in middle childhood. Journal of Clinical Child Psychology, 30, 349363 .

127. Shields, A., Ryan, R. M., \& Cicchetti, D. (2001). Narrative representations of caregivers and emotion dysregulation as predictors of maltreated children's rejection by peers. Developmental Psychology, 37, 321-337.

128. Sourander, A., Klomek, A. B., Niemela, S., Haavisto, A., Gyllenberg, D., Helenius, H., et al. (2009). Childhood predictors of completed and severe suicide attempts: Findings from the Finnish 1981 Birth Cohort Study. Archives of General Psychiatry, 66, 398-406.

129. Spriggs, A. L., Iannotti, R. J., Nansel, T. R. \& Haynie, D. L. (2007). Adolescent bullying involvement and perceived family, peer and school relations: Commonalities and differences across race/ethnicity. Journal of Adolescent Health, 41, 283-293.

130. Springer, K. W., Sheridan, J., Kuo, D., \& Carnes, M. (2007). Longterm physical and mental health consequences of childhood physical abuse: Results from a large population-based sample of men and women. Child Abuse \& Neglect, 31, 517-530.

131. Stewart, A., Livingston, M., \& Dennison, S. (2008). Transitions and turning points: Examining the links between child maltreatment and juvenile offending. Child Abuse \& Neglect, 32, 51-66.

132. Stockdale, M. S., Hangaduambo, S., Duys, D., Larson, K., \& Sarvela, P. D. (2002). Rural elementary students', parents', and teachers' perceptions of bullying. American Journal of Health Behavior, 26, 266-277.

133. Stocker, C. M., \& Youngblade, L. (1999). Marital conflict and parental hostility: Links with children's sibling and peer relationships. Journal of Family Psychology, 13, 598-609.

134. Stuwig, J. (2005). The relation of child maltreatment to shame and guilt among adolescents: Psychological routes to depression and delinquency. Child Maltreatment, 10, 324-336.

135. Stuewig, J., \& McCloskey, L. A. (2005). The relation of child maltreatment to shame and guilt among adolescents: Psychological routes to depression and delinquency. Child Maltreatment, 10, 324336.

136. Swearer, S. M., Peugh, J., Espelage, D. L., Siebecker, A. B., Kingsbury, W. L., \& Bevins, K. S. (2006). A socioecological model for bullying prevention and intervention in early adolescence: An exploratory examination. In S. R. Jimerson \& M. J. Furlong (Eds.), Handbook of school violence and school safety: From research to practice (pp. 257-273). Mahwah, NJ: Erlbaum.

137. Tajima, E. A. (2004). Correlates of the co-occurrence of wife abuse and child abuse among a representative sample. Journal of Family Violence, 19, 399-410.

138. Thornberry, T. P., Ireland, T. O., \& Smith, C. A. (2001). The importance of timing: The varying impact of childhood and adolescent maltreatment on multiple problem outcomes. Development and Psychopathology, 13, 957-979.

139. Toblin, R. L., Schwartz, D., Gorman, A. H., \& Abou-ezzeddine, T. (2005). Social-cognitive and behavioral attributes of aggressive victims of bullying. Journal of Applied Developmental Psychology, 26, 329-346.

140. Toth, S. L., Manly, J. T., \& Cicchetti, D. (1992). Child maltreatment and vulnerability to

141. depression. Development and Psychopathology, 4, 97-112.

142. Trickett, P. K., \& Kuczynski, L. (1986). Children's misbehaviors and parental discipline

143. strategies in abusive and nonabusive families. Developmental Psychology, 22, 115-123.

144. Turner, H. A., Finkelhor, D., \& Ormrod, R. (2006). The effect of lifetime victimization on the

145. mental health of children and adolescents. Social Science \& Medicine, 62, 13-27.

146. Tyler, K. A., Hoyt, D. R., Whitbeck, L. B., \& Cauce, A. M. (2003). The impact of childhood sexual abuse on later sexual victimization among runaway youth. Journal of Research on Adolescence, 11, 151-176.

147. U.S. Department of Health and Human Services, Administration on Children, Youth and Families (2009). Child maltreatment 2007. Washington, DC: U.S. Government Printing Office. 
148. Weiss, B., Caron, A., Ball, S. Tapp, J., Johnson, M., \& Weisz, J. R. (2005). Iatrogenic effects of group treatment for antisocial youths. Journal of Consulting and Clinical Psychology, 73, 1036-1044

149. White, S. O., \& Straus, M. A. (1981). The implications of family violence for rehabilitation strategies. In S. E. Martin, L. B. Sechrest, $\&$ R. Redner (Eds.), New directions in the rehabilitation of criminal offenders (pp. 255-288). Washington, DC: National Academies Press.

150. Widom, C. (1989). The cycle of violence. Science, 244, 160-166.

151. Wolfe, D. A., Scott, K., Wekerle, C., \& Pittman, A. L. (2001). Child maltreatment: Risk of adjustment problems and dating violence in adolescence. Journal of the American Academy of Child \& Adolescent Psychiatry, 40, 282-289.

152. Wolfe, D. A., Wekerle, C., Scott, K., Straatman, A. L., \& Grasley, C. (2004). Predicting abuse in adolescent dating relationships over 1 year: The role of child maltreatment and trauma. Journal of Abnormal Psychology, 113, 406-415.

153. Zimmermann, P., Maier, M. A., Winter, M., \& Grossmann, K. E. (2001). Attachment and adolescents' emotion regulation during a joint problem-solving task with a friend. International Journal of Behavioral Development, 25, 331-343.

154. Zins, J. E., Weissberg, R. P., Wang, M. C., \& Walberg, H. J. (Eds.). (2004). Building school success through social and emotional learning. New York: Teachers College Press.

155. Zingraff, M. T., Leiter, J., Myers, K. A., \& Johnsen, M. C. (1993). Child maltreatment and youthful problem behavior. Criminology, 31 , 173-202. 